\title{
Electronic cigarettes - possible long-term health impact
}

\section{Țigările electronice - posibil impact pe termen lung asupra sănătății}

Ana Maria Alexandra STĂNESCU ${ }^{1}$, Daniela Oana TOADER ${ }^{1,2}$,

Horia LĂZĂRESCU ${ }^{3}$, Andrei KOZMA ${ }^{3,4}$, Anca A. SIMIONESCU ${ }^{1,5}$,

Daniela MIRICESCU ${ }^{1,6}$, Florica ŞANDRU ${ }^{1,7}$,

Camelia Cristina DIACONU ${ }^{1,8}$

1Universitatea de Medicină și Farmacie „Carol Davila“, București, România

2Obstetrică, Ginecologie și Neonatologie, INSC „Alessandrescu Rusescu“ - Clinica Polizu,

București, România

IInstitutul National pentru Recuperare, Medicină Fizică și Balneoclimatologie, București

4Institutul Național pentru Sănătatea Mamei și Copilului „Alessandrescu-Rusescu“, București,

România

${ }^{5}$ Departamentul de Obstetrică și Ginecologie, Spitalul Filantropia, București, România

${ }^{6}$ Disciplina de Biochimie, Facultatea de Medicină Dentară, Universitatea de Medicină și Farmacie „Carol Davila“, București, România

${ }^{7}$ Spitalul Universitar de Urgență Elias, București, România

${ }^{8}$ Spitalul Clinic de Urgență, București, România

\begin{abstract}
Electronic cigarettes are increasingly popular devices that deliver nicotine through aerosols, not burning as in the case of classic cigarettes. Electronic cigarette traders claim that these types of cigarettes are safer than conventional cigarettes and that their use facilitates smoking cessation. However, there are many question marks regarding the long-term safety of using electronic cigarettes. In this review, we wanted to highlight the many vagueness and their possible effect on health.
\end{abstract}

Keywords: electronic cigarette, safety, health

\section{REZUMAT}

Țigările electronice sunt dispozitive din ce în ce mai populare care livrează nicotina prin aerosoli, nu prin ardere, ca în cazul țigărilor clasice. Comercianții de țigări electronice susțin faptul că acest tip de țigări sunt mai sigure decât țigările convenționale și că utilizarea lor facilitează renunțarea la fumat. $C$ u toate acestea, există multe semne de întrebare cu referire la siguranța pe termen lung a utilizării țigărilor electronice. În acest articol, ne-am dorit să evidențiem numeroasele neclarități și posibilul lor efect asupra sănătățiii.

Cuvinte cheie: țigară electronică, siguranță, sănătate 


\section{INTRODUCERE}

Țigările electronice sunt dispozitive din ce în ce mai populare, care livrează nicotina prin aerosoli, nu prin ardere, ca în cazul țigărilor clasice. Ele pot fi utilizate și fără conținut de nicotină sau cu adaos de arome precum cafea, vanilie, cireșe, caramel etc. Aerosolul generat dintr-o țigară electronică este denumit în mod uzual „vapor“. Vaporul se referă la starea gazoasă a unei substanțe; în schimb, un aerosol este o suspensie de particule fine de lichid, solid sau ambele într-un gaz. În urma unui puf, aerosolul este livrat la nivel bucal și în plămânii utilizatorului prin inhalare, după care aerosolul rămas este expirat în mediu $(1,2)$.

Comercianții de țigări electronice susțin faptul că acest tip de țigări sunt mai sigure decât țigările convenționale și că utilizarea lor facilitează renunțarea la fumat; cu toate acestea, producătorii de țigări electronice nu oferă informații complete despre substanțele chimice utilizate în procesul de fabricație sau substanțele chimice care pot fi eliberate sau sintetizate în timpul procesului de generare a aerosolului în timpul utilizării (3).

\section{ASPECTE ALE UTILIZATORILOR DE ȚIGĂRI ELECTRONICE ŞI PROBLEMELE DE SĂNĂTATE PUBLICĂ}

În general, persoanele albe nonhispanice, actuali fumători, adulții tineri și cei cu studii superioare și venituri peste medie percep e-țigările ca fiind mai puțin dăunătoare decât produsele convenționale din tutun și sunt mai predispuși să le folosească (4). În 2012 și 2013, unele sondaje au raportat că majoritatea utilizatorilor de țigarete electronice sunt foști sau actuali fumători, de asemenea, 40-70\% dintre toți adulții au auzit despre țigaretele electronice, iar 3-7\% din populația adultă a folosit țigarete electronice $(5,6)$.

Kralikova și colab. au arătat în 2012 că aproape $20 \%$ dintre fumătorii care încearcă țigările electronice vor deveni utilizatori obișnuiți ai acestora (7). Nu există o statistică exactă cu referire la numărul persoanelor fumătoare care recurg la țigările electronice pentru a stopa fumatul, pentru a continua numai cu țigările electronice sau pentru a deveni fumători micști. Unele studii susțin că persoanele care trec la țigările electronice, cu intenția de a renunța la fumat sau de a reduce fumatul, ajung să utilizeze dublu țigările electronice față de țigările convenționale, mai ales în locurile în care fumatul convențional este restricționat $(8,9)$. Preferința, prevalența și scopul utilizării țigărilor electronice sunt foarte diferite în populație, fiind foarte greu de a determina un model predictiv în ceea ce privește renunțarea la fumatul convențional cu ajutorul țigărilor electronice.

Datele din Studiul Național al Tutunului pentru Tineret din perioada 2011-2012 au arătat că în rândul elevilor din clasele VI-XII utilizarea curentă a țigaretelor electronice ( $\geq 1$ zi în ultimele 30 de zile) a crescut de la 1,1\% în 2011 la 2,1\% în 2012 (10). De asemenea, un sondaj pe 40.000 de elevi de liceu și școală generală din 200 de școli a arătat că utilizarea de țigarete electronice este mai mare la fumătorii actuali și printre cei care intenționează să renunțe la fumat (10).

Din ce în ce mai mult, există marketing și publicitate robustă folosind celebrități și arome atrăgătoare (de exemplu, ciocolată, căpșuni și vanilie) pentru a face țigările electronice mai atractive, atrăgând în special copiii și adolescenții (11). Deși inițial marketingul pentru țigările electronice a fost realizat prin internet și rețelele de socializare, din ce în ce mai mult publicitatea se regăsește la televizor, la radio și în presa scrisă, incluzând zonele de marketing, unde reclama la țigările convenționale nu este permisă (12).

Problemele majore de sănătate publică în legătură cu țigările electronice sunt legate de contribuția acestora la reducerea prejudiciului general legat de tutun prin încetarea completă sau prin reducerea numărului de țigarete fumate, reducerea expunerii pasive la fum de țigară și diminuarea influenței industriei tutunului. Nu se poate prezice încă dacă tehnologia emergentă a țigărilor electronice va lua locul țigărilor convenționale sau dacă se va continua utilizarea duală (13).

\section{EFECTE ASUPRA SĂNĂTĂȚII}

Efectele generale asupra sănătății în urma utilizării țigărilor electronice trebuie luate în considerare atât în contextul toxicității intrinseci a țigărilor electronice, cât și în ceea ce privește toxicitatea lor relativă, comparativ cu efectele dăunătoare cunoscute ale fumatului țigărilor convenționale. în general, efectele asupra sănătății prin utilizarea țigărilor electronice nu au fost bine studiate, iar potențialul prejudiciu suferit de utilizarea pe termen lung a acestor dispozitive rămâne complet necunoscut.

Unele studii au examinat efectele asupra sănătății luând în considerare evaluarea toxicologică a lichidelor și a aerosolilor din țigara electronică. Nivelurile de toxicitate ale lichidelor utilizate în țigara electronică și ale aerosolilor variază în funcție de formulă (nicotină, arome, apă, glicerină și propilenglicol) și design-ul specific al dispozitivu- 
lui (expunerea la diverse tipuri de metal, nivelul de încălzire) (14). Potențialele metale și nanoparticule derivate din bobinele de încălzire pot include staniu, fier, nichel și crom, iar alte materiale pot fi reprezentate de ceramică, materiale plastice, cauciuc, fibre cu filament și spume (15). E-lichidele conțin de obicei multe arome, inclusiv aromă de tutun, iar în arome se pot găsi N-nitrozamină, tutun, hidrocarburi aromatice policiclice și compuși organici volatili (15).

Într-un produs pentru țigara electronică a fost găsit dietilenglicol, în alte produse au fost găsite rimonabant, substanță utilizată pentru pierderea în greutate, și tadalafil, utilizat în disfuncția erectilă (16).

Majoritatea e-lichidelor conțin $24 \mathrm{mg} / \mathrm{ml}, 18$ $\mathrm{mg} / \mathrm{ml}, 12 \mathrm{mg} / \mathrm{ml}$ sau $6 \mathrm{mg} / \mathrm{ml}$ nicotină și sunt calificate de producători cu o concentrație mare, medie sau mică (17). Nivelurile de nicotină din sânge sunt în general mai scăzute în cazul țigării electronice decât în cazul țigărilor convenționale, însă utilizatorii unor sisteme de rezervoare de e-țigarete cu baterii mai puternice, care încălzesc lichidele la temperaturi mai ridicate, pot atinge niveluri de nicotină din sânge comparabile cu cele ale fumătorilor de țigări convenționale (18). Nu a fost determinată măsura în care nicotina inhalată dintr-o țigară electronică este absorbită prin plămâni sau prin gât și căile respiratorii superioare. În afară de dependența nicotinei, îngrijorările sunt legate de capacitatea nicotinei de a elibera catecolamine, incluzând efectele hemodinamice (creșterea ritmului cardiac, creștere tranzitorie a tensiunii arteriale, vasoconstricția paturilor coronare și a altor paturi vasculare), efectele adverse asupra lipidelor și inducerea rezistenței la insulină (19, 20,21).

Deși efectele adverse ale nicotinei din țigările electronice asupra sănătății nu sunt cunoscute, este probabil să fie mult mai mici decât cele ale fumatului convențional, dar ar putea fi semnificative la persoanele cu boli cardiace (22). $O$ altă problemă este ridicată cu privire la toxicitatea ingerării nicotinei din lichidul pentru țigara electronică și gradul de expunere dermică la aceste lichide. Intoxicația cu nicotină provoacă în mod frecvent amețeli, greață, vărsături, paloare, tahicardie și transpirație (23). Alte efecte ale intoxicației cu nicotină sunt reprezentate de dureri abdominale, salivație, lăcrimare și diaree, confuzie, agitație, letargie, convulsii și posibil deces (24-26). Concentrațiile de nicotină din lichidele de țigară electronică sunt suficient de mari pentru a fi fatale pentru un copil, chiar dacă sunt ingerați câțiva mililitri (27). Alcaloizii minori de tutun și nitrozaminele specifice tutunului se găsesc în unele lichide pentru țigările electronice, acestea având un puternic potențial cancerigen $(28,29)$.

Încălzirea glicerolului poate forma acroleină, care este un agent iritant și oxidant despre care se crede că ar contribui la efectele adverse pulmonare și cardiovasculare ale fumatului de țigări. Analizele emisiilor din țigări au constatat în principal prezența formaldehidei, a acetaldehidei și a acroleinei, împreună cu niveluri scăzute de toluen, xilen, benzen și butadienă $(30,31)$. Deși acești compuși sunt potențial toxici, nivelurile emisiilor de e-țigări sunt de multe ori mai mici decât cele găsite în fumul de țigară $(32,33)$.

Niveluri detectabile de metale precum staniu, argint, fier, nichel, cadmiu și cupru au fost detectate în unele, dar nu în toate țigările electronice, acestea putând fi generate din elementul de încălzire. Nanoparticulele prezente în unii aerosoli ai țigărilor electronice au fost raportate, de asemenea, că ar conține niveluri de staniu, crom și nichel $(15,34)$. S-a constatat că numărul de particule din aerosolul din țigara electronică a fost influențat de conținutul de nicotină lichidă și de timpul de puf, iar nivelurile mai ridicate de particule au fost generate de țigările electronice care conțineau concentrații mai mari de nicotină $(35,36)$.

Studiile au arătat că citotoxicitatea nu a fost cauzată de nicotină, dar a fost corelată cu numărul și concentrația de substanțe chimice aromatizante și, în general, pare să fie legată de concentrațiile și numărul de arome utilizate și nu are legătură cu nicotina $(37,38)$. Preocuparea deosebită în ceea ce privește citotoxicitatea aromelor este îndreptată asupra efectelor cinamaldehidei, o aromă care este aprobată pentru utilizare în alimente, dar poate fi periculoasă atunci când este inhalată $(39,40)$.

\section{CONCLUZII}

Deși se presupune că fumatul țigărilor electronice este sigur, nu se cunosc cu certitudine efectele pe termen lung. În acest context, putem evidenția lipsa studiilor, mai ales din cauza impedimentelor care survin și a perioadei relativ scurte de utilizare a acestor dispozitive. $O$ dată cu trecerea timpului, viitoarele studii vor putea evidenția mai bine posibilele efecte negative asupra sănătății în urma utilizării țigărilor electronice.

\section{Mențiune}

Toți autorii au contribuție egală la realizarea acestui articol.

Conflict of interest: none declared Financial support: none declared 


\section{BIBLIOGRAFIE}

1. Trtchounian A, Williams M, Talbot $P$. Conventional and electronic cigarettes (e-cigarettes) have different smoking characteristics. Nicotine Tob Res 2010; 12:905-912.

2. Pauly J, Li Q, Barry MB. Tobacco-free electronic cigarettes and cigars deliver nicotine and generate concern. Tob Control 2007; 16:357.

3. Henningfield JE, Zaatari GS. Electronic nicotine delivery systems: Emerging science foundation for policy. Tob Control 2010;19:89-90.

4. Pearson JL, Richardson A, Niaura RS et al. E-cigarette awareness, use, and harm perceptions in US adults. Am J Public Health. 2012; 102:1758-1766.

5. King BA, Alam S, Promoff $\mathrm{G}$ et al. Awareness and ever-use of electronic cigarettes among U.S. Adults, 2010-2011. Nicotine Tob Res. 2013;15:1623-1627.

6. Regan AK, Promoff G, Dube SR, Arrazola R. Electronic nicotine delivery systems: Adult use and awareness of the "e-cigarette" in the USA. Tob Control. 2013; 22:19-23.

7. Kralikova E, Novak J, West $\mathrm{O}$ et al. Do e-cigarettes have the potential to compete with conventional cigarettes? A survey of conventional cigarette smokers' experiences with e-cigarettes. Chest. 2013; 144:1609-1614.

8. Douptcheva N, Gmel G, Studer J et al. Use of electronic cigarettes among young Swiss men. J Epidemiol Commun Health. 2013; 67:1075-1076.

9. Dawkins L, Turner J, Roberts A, Soar K. "Vaping" profiles and preferences: An online survey of electronic cigarette users. Addiction. 2013;108:1115-1125.

10. Dutra LM, Glantz SA. Electronic cigarettes and conventional cigarette use among U.S. adolescents: A cross-sectional study. JAMA Pediatr. 2014;168(7):610-617.

11. Choi K, Fabian L, Mottey N et al. Young adults' favorable perceptions of snus, dissolvable tobacco products, and electronic cigarettes: Findings from a focus group study. Am J Public Health. 2012; 102:2088-2093.

12. Paek HJ, Kim S, Hove T, Huh JY. Reduced harm or another gateway to smoking? Source, message, and information characteristics of e-cigarette videos on YouTube. J Health Commun. 2014; 19:545-560.

13. Harrell PT, Simmons VN, Correa JB et al. Electronic nicotine delivery systems ("e-cigarettes"): review of safety and smoking cessation efficacy. Otolaryngology Head Neck Surg. Accesat 2019 https:// www.reliasmedia.com/articles/136984electronic-cigarette-and-nicotine-toxicity
14. Orr MS. Electronic cigarettes in the USA: A summary of available toxicology data and suggestions for the future. Tob Control. 2014; 23(suppl 2):ii18-ii22.

15. Williams M, Villarreal A, Bozhilov $K$ et al. Metal and silicate particles including nanoparticles are present in electronic cigarette cartomizer fluid and aerosol. PLoS One. 2013; 8:e57987.

16. Palazzolo DL. Electronic cigarettes and vaping: A new challenge in clinical medicine and public health: A literature review. Front Public Health. 2013;1:56.

17. Vaper Train. http://www.vapertrain.com/ page/hdics. Accessed 2019.

18. Vansickel AR, Eissenberg T. Electronic cigarettes: Effective nicotine delivery after acute administration. Nicotine Tob Res. 2013; 15:267-270.

19. Centers for Disease Control and Prevention (US); National Center for Chronic Disease Prevention and Health Promotion (US); Office on Smoking and Health (US). How Tobacco Smoke Causes Disease: The Biology and Behavioral Basis for SmokingAttributable Disease: A Report of the Surgeon General. Atlanta, GA: Centers for Disease Control and Prevention; 2010, Accesat 2019 https://www.ncbi.nlm.nih.gov/ pubmed/21452462.

20. Manea M, Marcu D, Motofei I et al. Cardiovascular risk in patients with inflammatory bowel diseases: A review. Rom Biotechnol Lett. 2019;24(2):366-373.

21. Manea M, Marcu D, Stoian AP et al. Heart Failure with preserved ejection fraction and atrial fibrilation: A review. Rev Chim (Bucharest) 2018;69(11):4180-4184.

22. Diaconu CC, Marcu DR, Bratu OG et al. Beta-blockers in cardiovascular therapy: A review. J Mind Med Sci 2019;6(2):216-223.

23. Diaconu $C$, Bălăceanu $A$, Bartoş $D$. Venous thromboembolism in pregnant woman - a challenge for the clinician. Central European Journal of Medicine 2013; 8(5):548-552.

24. Solarino B, Rosenbaum F, Riesselmann B et al. Death due to ingestion of nicotinecontaining solution: Case report and review of the literature. Forensic Sci Int. 2010; 195:e19-e22.

25. Miricescu D, Totan A, Stanescu II et al. Periodontal disease and systemic health. Ro Med J. 2019;66(3):195-199.

26. Stefani C, Grajdeanu IV, Serban B et al. Abordarea depresiei în practica medicului de familie. Ro Med J. 2019;66(1):24-28.

27. Etter JF, Zather E, Svensson S. Analysis of refill liquids for electronic cigarettes. Addiction. 2013; 108:1671-1679.

28. Hecht SS. Biochemistry, biology, and carcinogenicity of tobacco-specific
N-nitrosamines. Chem Res Toxicol. 1998; 11:559-603.

29. Totan A, Totan C, Stănescu AMA et al. Lysyl oxidase (LOX) - A future new ally on the stage of the fight against cancer. Ro Med J. 2019;66(3):214-216.

30. Ismahil MA, Hamid T, Haberzettl P et al. Chronic oral exposure to the aldehyde pollutant acrolein induces dilated cardiomyopathy. Am J Physiol Heart Circ Physiol. 2011; 301:H2050-2060.

31. Paraschiv B, Dediu G, lancu A, Bratu O, Diaconu $C$. Superior vena cava syndrome - review. Archives of the Balkan Medical Union 2017;52(1):39-43.

32. Goniewicz ML, Kuma T, Gawron M, Knysak $\mathrm{J}$, Kosmider L. Nicotine levels in electronic cigarettes. Nicotine Tob Res. 2013; 15:158-166.

33. Paraschiv B, Toma CL, Diaconu C. Bronchiolo-alveolar carcinoma in a young patient: A case report. Archivos de Bronconeumología 2013;49(7):315-316.

34. Miricescu D, Totan A, Stănescu AMA, Stănescu II, Stefani C, Greabu M. Deficiența de vitamina $\mathrm{D}$ și rezistența la insulină. Ro J Med Pract.2019; 14,3(67):227-232.

35. Fuoco FC, Buonanno G, Stabile L, Vigo P. Influential parameters on particle concentration and size distribution in the mainstream of e-cigarettes. Environ Pollut. 2014; 184:523-529.

36. Diaconu CC, Arsene D, Paraschiv B, Bălăceanu A, Bartoş D. Hyponatremic encephalopathy as the initial sign of neuroendocrine small cell carcinoma - case report. Acta Endocrinologica 2013; IX(4): 637-642.

37. Bahl V, Lin S, Xu N, Davis B, Wang YH, Talbot $P$. Comparison of electronic cigarette refill fluid cytotoxicity using embryonic and adult models. Reprod Toxicol. 2012; 34:529-537.

38. Diaconu C, Bălăceanu A, Moroşan E. Sepsis biomarkers: Past, present and future. Farmacia 2015;63(6):811-815.

39. Popa AR, Vesa CM, Uivarosan D, Jurca CM, Isvoranu G, Socea B, Stănescu AMA, lancu MA, Scarneciu I, Zaha DC. Cross Sectional Study Regarding the Association Between Sweetened Beverages Intake, fast-food Products, Body Mass Index, Fasting Blood Glucose and Blood Pressure in the Young Adults from North-western Romania. Revista de Chimie 2019; 70(1):156-160.

40. Behar RZ, Davis B, Wang Y, Bahl V, Lin S, Talbot $P$. Identification of toxicants in cinnamon-flavored electronic cigarette refill fluids. Toxicol In Vitro. 2014; 28:198-208. 